\title{
Constructing History in Uganda
}

Andrew Reid

$\mathrm{UCL}$

A consideration of the potential for Historical Archaeology in Eastern Africa, first needs to explore the interaction between Archaeology and History and understand the impediments that have grown between the two disciplines. ${ }^{1}$ Frequently in universities in sub-Saharan Africa, Archaeology has developed and remains within Departments of History. This has a range of consequences, including the recruitment of Arts and Humanities based students into Archaeology, as opposed to those with a more scientific background, and the protracted focus on issues of identity, sequence, and culture history. This also, in part, explains the tacit agreement in studies focusing on the last 500 years that, until recently, historians work on the more recent period that is better defined by texts and/or oral traditions and that archaeologists endeavour to explore earlier times. ${ }^{2}$ African History may have receded towards a much greater emphasis on colonial history, ${ }^{3}$ with archaeology creeping up the chronological shoreline to fill in the resultant gap, but Archaeology and History have rarely been

\footnotetext{
${ }^{1}$ As one historian colleague reminded me when in 1992 I joined the Archaeology Unit within the Department of History at the University of Dar es Salaam, "Archaeology is the handmaiden of History". For a discussion of the relationship between historians and archaeologists see J. Vansina, 'Historians, Are Archaeologists your Siblings', History in Africa, 22 (1995), 369-408, and P.T. Robertshaw, 'Sibling Rivalry? The intersection of archaeology and history', History in Africa, 27 (2000), 261-86. Unfortunately there has been little development of this discussion thereafter.

${ }^{2}$ See P.J. Lane and A. Reid, 'Editorial: Azania at 50', Azania: Archaeological Research in Africa, 50 (2015), 42536.

${ }^{3}$ R. Reid, 'Past and presentism: the "precolonial" and the foreshortening of African History', Journal of African History, 52 (2011), 135-55.
} 
combined. ${ }^{4}$ Clearly this separation does not serve to encourage the development of Historical Archaeology as it is recognised in other parts of the world..$^{5}$

It is first worthwhile exploring the potential of Historical Archaeology to investigate the past in a non-African setting. This potential is well illustrated by a recent study by Tania Kausmally of a paltry deposit of archaeological material, less than one cubic metre in volume, excavated from a basement in the Charing Cross area of London. ${ }^{6}$ The deposit is derived from the Craven Street Anatomy School that operated at the site from 1772 to 1778 . Historical documentation provides exceptional detail on the school and its founder William Hewson: Hewson presented lectures at and received awards from the Royal Society; his wife was a close friend of Benjamin Franklin, who lived on Craven Street at the time, and they subsequently corresponded; the catalogue from the auction of the anatomy school after its closure still exists, together with an indication of the purchaser and the price paid. These and other diverse historical sources provide exceptional detail about Hewson and his school, but the archaeological deposit contributes human and animal bone, glass and metal which detail the actual life of the school; the cadavers it illicitly acquired from 'Resurrection Men', the dissection of bodies and practicing of surgical techniques (including trepanation and amputation)

\footnotetext{
${ }^{4}$ Two very notable - and very different - exceptions to this are P.R. Schmidt, Historical Archaeology: $a$ structural approach in an African Culture (Westport CT, 1978), combining oral histories and archaeology to reconstruct cultural landscapes and D.L. Schoenbrun, A Green Place, A Good Place: agrarian change, gender and social identity in the Great Lakes region to the $15^{\text {th }}$ century (London, 1998), who makes excellent use of archaeological, palaeoenvironmental, and ethnographic data to flesh out his histories based on comparative linguistics.

${ }^{5}$ See for instance C.E. Orser, A Historical Archaeology of the Modern World (New York, 1996).

${ }^{6}$ T. Kausmally, 'William Hewson (1739-1774) and the Craven Street Anatomy School - anatomical teaching in the $18^{\text {th }}$ century' (unpublished PhD thesis, University College London, 2015).
} 
in the weeks before they completely putrefied, ${ }^{7}$ the vivisection experiments conducted on the more than 44 different animal species identified, and Hewson's early exploration of the development of microscopy with the help of London's leading glass manufacturers. The result is a unique insight into the production of western scientific knowledge and the debatable foundations upon which modern science was constructed. The example, which is in truth exceptional for the Historical Archaeology of any part of the world, demonstrates that the greatest potential for Historical Archaeology lies where the archaeological record interweaves with rich and diverse historical sources. Even at the heart of late eighteenth-century London, with its extensive bureaucratic records, personal accounts and welldefined historical traditions, archaeology has a significant role to play in teasing out the subtleties of a particular topic.

Inherent in the best examples of Historical Archaeology with their strong archaeological and historical sources is the ability to incorporate perspectives from history, archaeology, and anthropology. In general, historians, archaeologists, and anthropologists would all now recognise that pasts are constantly being created, modified, adapted, and/or invented. ${ }^{8}$ This of course means that pasts continue to be constructed in the present moment, independent of and unregulated by academic discoveries and realisations. Indeed, academic pasts can be argued to have no more veracity or value, than those generated by other knowledge sources, particularly those that may be

\footnotetext{
${ }^{7}$ Probably as a direct result of this thoroughly unhealthy working environment, Hewson died of septicaemia in 1874, Ibid, 121.

${ }^{8}$ For example D.W. Cohen and E.S.A. Odhiambo, Siaya: the historical anthropology of an African landscape (London, 1989), E. Ohnuki-Tierney (ed.), Culture through Time (Stanford, 1990), A.B. Stahl, Making History in Banda (Cambridge, 2001). For a very specific Ugandan example see J. Willis, 'Two lives of Mpamizo: understanding dissonance in oral history', History in Africa, 23 (1996), 319-332.
} 
termed local or indigenous. ${ }^{9}$ It is within the resultant ambiguities of constructions of the past that Historical Archaeology holds its greatest appeal in sub-Saharan Africa, with its ability to consider those not represented by the privileges of written text or approved oral tradition. Focusing as it does on material culture, archaeology has the ability to explore the mundane and the values and associations with which that materiality has subconsciously been imbued. It is the examination and critique of what may be considered 'obvious truisms' through an exploration of context and meaning that gives Historical Archaeology its real vitality. ${ }^{10}$ This contribution seeks to consider the construction of history through materiality within Uganda and in so doing assesses the potential for creating future historical archaeologies, particularly in relation to developing socially engaged practice. First it will be necessary to consider the nature of history as currently perceived in Uganda.

\section{THE NOTION OF HISTORY IN UGANDA}

At the outset it must be recognised that Uganda, in common with many African nations has a superficially strong sense of history. Historical studies of the precolonial past clearly demonstrate that there was considerable importance in establishing historical credentials, with new dynasties

\footnotetext{
${ }^{9}$ In an Australian colonial context, appropriate to sub-Saharan Africa, it is argued that the recognition of other knowledge systems is a necessary prerequisite to research: I.J. McNiven and L. Russell, Appropriated Pasts: indigenous peoples and the colonial culture of Archaeology (Oxford, 2005). For a discussion of the use of the term indigenous in African contexts see P.J. Lane, 'Being "indigenous" and being "colonised" in Africa: contrasting experiences and their implications for a postcolonial archaeology', in N. Ferris, R. Harrison and M.V. Wilcox (eds.), Rethinking Colonial Pasts Through Archaeology (Oxford, 2014), 423-44.

${ }^{10}$ S. Tarlow, The Archaeology of Improvement in Britain, 1750-1850 (Cambridge, 2007), 195.
} 
proclaiming links to old and drawing moral authority from such associations. ${ }^{11}$ From the earliest encounters with Europeans, the importance given to historical legitimacy and length of tradition suggests a well-formed and well-rehearsed historical sense. The early encounters also demonstrated that Europeans associated great significance to these histories. The colonial encounter and indirect rule only served to magnify historical traditions and emphasise the importance of elite histories. ${ }^{12}$ Actions and events, some drawn from precolonial examples, others adopted, served to create traditions that had perceived historical authenticity. ${ }^{13}$ These elites drew on historical legitimacy to negotiate their tenuous hold on power, challenged both by the European presence and the need to convince the populace that they retained their authority of old. ${ }^{14}$

Furthermore, indirect rule, at least in southern Uganda, ensured that precolonial political systems continued to have a degree of relevance as power structures in colonial times, and indeed episodes of disagreement with colonial administrators served to reinvigorate political legitimacy, such as the exile of Mutesa from 1953-5. This exile provided Mutesa with renewed (as opposed to 'traditional') political authority ${ }^{15}$ prior to Uganda's independence, a circumstance which culminated in his appointment as the first President of Uganda. Indeed, the subsequent exile of the kabaka in 1966, the abolition of the kingdoms in 1967 and their partial reinstatement in 1993 have all served

\footnotetext{
${ }^{11}$ See Schmidt, Historical, with regards to religion and political succession in Buhaya, and D.L. Schoenbrun, 'A mask of calm: emotion and founding the kingdom of Bunyoro in the $16^{\text {th }}$ century', Comparative Studies in Society and History, 55 (2013), 634-64, concerning the Bito and Bunyoro.

${ }^{12}$ See for instance D. Henige, "'The disease of writing": Ganda and Nyoro kinglists in a newly literate world', in J.C. Miller (ed.), The African Past Speaks (Folkestone, 1980), 240-61.

13 For example T. Ranger, 'The invention of tradition in colonial Africa', in E. Hobsbawm and T. Ranger (eds.), The Invention of Tradition (Cambridge, 1983), 211-62.

${ }^{14}$ An excellent example from Uganda is provided by J. Willis, 'Killing Bwana: peasant revenge and political panic in Early Colonial Ankole', Journal of African History, 35 (1994), 379-400.

${ }^{15}$ C. Wrigley, Kingship and State: the Buganda dynasty (Cambridge, 1996), 19.
} 
to renew the contemporary significance of this form of political leadership. Very recently serious rioting has occurred on an almost annual basis involving supporters of the kabaka angered at the denial of his political autonomy and perceived slights against him on the part of government. When in March 2010, the main structure of the Kasubi tombs, burial place of the last four kabaka and Uganda's only cultural World Heritage Site, burned down it lead to protest and conflict with the police. These various events within Buganda have served to perpetuate the contemporary legitimacy of the current kabaka and the association of popular senses of history with current kingship. ${ }^{16}$ This association of history with kings is so overpowering in Uganda generally, that areas with no or limited prior notions of kingship have sought to develop previously unrecognised traditions. Hence, efforts have recently been made to develop a single unified royalty in places like Busoga, Bundibugyo, and Acholi.

Thus, whilst it can be said that there is a strong sense of History in Uganda, from the perspective of historians and archaeologists alike it is not historically rigorous. This therefore offers fertile ground for critique and research that addresses fundamental preconceptions in the national psyche.

\section{HISTORICAL SITES IN UGANDA}

Having defined the general sense of history in Uganda, it is then necessary to consider the kinds of archaeological sites that have in the past been associated with Historical Archaeology. Partly as a result of the connection between southern and western Uganda and local colonial administrations, several sites and locations were recognised as being of historical interest. Generally, these sites are from earlier time periods, on the margins of historical memory, and their examination served to

\footnotetext{
${ }^{16}$ This is not to say, of course, that other means around which to construct the past do not exist. See $\mathrm{N}$. Kodesh, Beyond the Royal Gaze: clanship and public healing in Buganda (London, 2010).
} 
extend political legitimacy further back into the past. An obvious example of this Historical Archaeology is Bweyorore, a site that became regarded as a capital of Nkore in the 1950 s. ${ }^{17}$ Initial excavations at the site largely had the intention of verifying oral tradition linking the site with specific kings from Nkore kinglists. ${ }^{18}$ Dating of the deposits by the radiocarbon method was not surprisingly inconclusive and little attempt was made to explore the structure and dynamics of the settlement. Later excavations demonstrated that Bweyorere was one of the best preserved precolonial capitals in the whole of the Great Lakes region and one of the few with the archaeological potential for detailed investigation. ${ }^{19}$ Regrettably, the potential for investigation of this site was never fully realised and in 2014 it was destroyed by a road construction company improving the nearby main road, even though it had been a gazetted national monument for decades and was therefore owned by and under the protection of the state. Most surprisingly, the destruction of the site appears to have been encouraged by individuals claiming to be representatives of the Ankole kingdom who sold the land - to which they did not have legal title suggesting that those who were most closely associated with the historical site recognised no value in its protection and conservation.

\footnotetext{
${ }^{17}$ As recognised by R. Oliver, 'Ancient capital sites of Ankole', Uganda Journal, 23 (1959), 51-63, but curiously not by H.F. Morris, 'Historic sites in Ankole', Uganda Journal, 20 (1956), 177-81.

${ }^{18}$ M. Posnansky, 'The excavation of an Ankole capital site at Bweyorere', Uganda Journal, 32 (1968), 165-82. For a critique of this approach, see P.R. Schmidt, 'Oral traditions, archaeology and history: a short reflective history', in P.T. Robertshaw (ed.), A History of African Archaeology (London, 1990), 252-70. See also Schmidt, this volume.

${ }^{19}$ A. Reid, 'The emergence of states in the Great Lakes region', in P.R. Mitchell and P.J. Lane (eds.), Handbook of African Archaeology (Oxford, 2013), 883-95.
} 
Similar ambiguities and ambivalences are evident at Bigo bya Mugenyi. Bigo had long been recognised as a place of historical importance, even if that history proved difficult to establish ${ }^{20}$ Its extensive ditches marked it as an important location in the construction of colonial monuments and encouraged its association with the poorly understood but administratively popular Cwezi, appealing to both British officials and royal courts. ${ }^{21}$ Possible associations with vaguely defined characters such as Ndahura, have been given greater legitimacy by fleeting use of the site as a refuge by Mwanga in the late nineteenth century ${ }^{22}$ and Yuweri Museveni and the NRA in the early $1980 \mathrm{~s}^{23}$ The resumption of regular archaeological visits to the site ${ }^{24}$ have registered the emergence of a spirit cult at the site and in the nearby landscape. ${ }^{25}$ These appear to be shortlived, with mediums rapidly

\footnotetext{
${ }^{20}$ E.J. Wayland, 'Notes on the Biggo bya Mugenyi; some ancient earthworks in northern Buddu', Uganda Journal, 2 (1934), 21-32. M. Posnansky, 'Bigo bya Mugenyi', Uganda Journal, 33 (1969), 125-10. See also
} Schmidt, this volume.

${ }^{21}$ These colonial ideas have been perpetuated into contemporary political discourse: P.R. Schmidt, 'Deconstructing Archaeologies of African Colonialism: making and unmaking the Subaltern', in N. Ferris, R. Harrison and M.V. Wilcox (eds.), Rethinking Colonial Pasts Through Archaeology (Oxford, 2014), 445-68.

22 Posnansky, Bigo.

${ }^{23}$ Informants encountered at Ntuusi in 1988 who had been with the NRA in hiding at Bigo, recalled the time in 1985 when they watched unobserved as John Sutton visited the site. Museveni's interest in Bigo (see Schmidt, Deconstructing) was greatly influenced by his time at the University of Dar es Salaam and his interaction with Walter Rodney, explaining the latter's use of Bigo as a case study: W. Rodney, How Europe Underdeveloped Africa (Washington, 1981).

${ }^{24}$ In the 1970s Idi Amin barred representatives of the Department of Antiquities from visiting sites such as Ntuusi and Bigo, because this promoted notions of the superiority of southern Ugandan history over that from the north, E.R. Kamunhangire, pers. comm. 1988. In the early 1980 s it was simply too dangerous.

${ }^{25}$ P.T. Robertshaw and E.R. Kamuhangire, 'The present in the past: archaeological sites, oral traditions, shrines and politics in Uganda', in G. Pwiti and R. Soper (eds.), Aspects of African Archaeology: papers from the $10^{\text {th }}$ Congress of the Pan African Association for Prehistory and Related Studies (Harare, 1996), 739-43. 
moving on and new mediums occupying the site. This has also sponsored the development of a significant ritualist presence living on the site.

The development of a ritual presence at Bigo is part of a much broader process of occupation and acquisition of sites by spiritualist practitioners, in many cases where no previous spiritualist presence was evident. The most overt expression of this spirituality is to be found at Ttanda, ten kilometres east of Mityana. Ttanda was examined by colonial geologists in the 1920s and was found to be a large collection of mine shafts sunk to extract kaolinite, ${ }^{26}$ probably for use in making tuyeres in the precolonial iron smelting process of the last few centuries, but possibly also for a range of other purposes, from assisting with pregnancy, via painting of initiates and bridal houses, through to improving digestion, pacifying victims of execution and preparing mediums for possession. Oral sources suggest that there was an important shrine nearby to Walumbe, the death spirit, run by the Colobus Monkey Clan which related to the shafts. ${ }^{27}$ By at least the mid twentieth century a direct association had emerged between the shafts, Walumbe, and the popular Ganda tradition of his flight from his pursuers through holes in the ground. ${ }^{28}$ By 2001 , the land had been acquired by a member of the Ganda elite who encouraged the proliferation of spiritual practice and thus sponsored the development of a hybrid religion. At Ttanda and elsewhere in Buganda ritual activity has developed in which short votive iron spears are brought to the site and placed in the ground by supplicants. ${ }^{29}$ From isolated and uniform votive spears and occasional cowries in 2001, in

\footnotetext{
${ }^{26}$ A.S. Taylor, 'Report on Ntanda', (unpublished report, Geological Survey Department, Uganda, 1921).

${ }^{27}$ Kodesh, Beyond, 55-6.

${ }^{28}$ E.C. Lanning, 'Notes on certain shafts in Buganda and Toro', Uganda Journal, 18 (1954), 187-9.

${ }^{29}$ This is similar to, but quite distinct from the iron spears, knives and bells that were deposited at the Luzira shrine and collected in 1929: E.J. Wayland, M.C. Burkitt and H.J. Braunholtz, 'Archaeological discoveries at Luzira', Man, 33 (1933), 29-47.
} 
2015 there are now forests of these artefacts placed around the important shrine shafts. ${ }^{30}$ There is also an increasing distinction of the characteristics of the votive spears: multiple, splayed, or bifurcated heads and twisted, bent, or otherwise modified mid-shafts. From an initial ritual focus on one or two of the mine shafts, this has been expanded to include dozens of the features, dedicated to the many spirits and gods recognised in precolonial Buganda. There are even shrines to Ndahura, incongruously incorporating pastoralist material culture in this otherwise firmly Ganda setting. Perhaps most surprisingly of all is that in 2015 two new shrines were developed outside the main complex. One is to Mukasa, Buganda's most important deity, but the polar opposite of Walumbe being associated with life and with white. The other is to Kiwanuka, associated traditionally with lightning, now having an adapted link with electricity and sponsoring a shrine to match decorated with electrical wire, light bulbs, fuse boxes, and drive shafts from motor engines (Fig. 1).

This spiritualisation of at least some of the archaeology in southern parts of Uganda is seemingly not happening elsewhere. In 2009, at the village of Agoro, in Kitgum District in the far north of Uganda, Dismas Ongwen, Sites and Monuments Officer with the Department of Antiquities and Museums came across a large archaeological site on a nearby hillside. This consists of a series of house platforms on the sides of the hill, with thick dry stone walls of up to fifty metres in length and two metres in height. At the highest part of the site there appears to be an open area with regulated access which suggests a public space for meetings and decision making. Even with this limited information the site would appear to be a population centre linked to processes of political centralisation amongst Acholi communities in the late seventeenth and eighteenth centuries. ${ }^{31}$

\footnotetext{
${ }^{30}$ Initial visits were made by the author as part of archaeological survey in Buganda in 2001 and 2002. Subsequent visits have been made in 2009, 2011, 2013, and 2015 as part of the "Studies in African Field Archaeology" undergraduate course at University College London. I am grateful to Peter Bisasso and Dismas Ongwen for their insights and help in understanding Ttanda.

${ }^{31}$ See R.R. Atkinson, Origins of the Acholi of Uganda, (2 ${ }^{\text {nd }}$ Ed., Kampala, 2010).
} 
Unfortunately, there has been almost no archaeology undertaken in northern Uganda as a whole, so there are no sites with which comparisons may be drawn. Equally, the terrible population displacement that has occurred in northern Uganda due to the conflict there which ended around 2006 has had great consequences for the retention and creation of social memory, with historical attachments to place and land being severely compromised. Essentially in Agoro today, there appear to be no memories of who may have lived at the archaeological site. Hence, in Agoro and northern Uganda more generally, historical and archaeological silences of the past are creating continued silences in the present.

\section{THE PROSPECTS FOR HISTORICAL ARCHAEOLOGY}

These examples demonstrate use, re-use, invention, and rejection at various archaeological sites in recent times and indicate that Ugandan communities are actively creating and consuming history that is perceived to fit their own needs. This strength of activity contrasts with the limitations of the archaeological record. Settlement in the region was usually short-term and dispersed, preventing the build-up of significant occupational debris. Structures were usually made of organic materials which leave little trace. The humidity and chemistry of soils further remove these traces and cause the destruction of palaeobotanical remains and animal bones in all but the most modified soil environments. Radiocarbon dating for the last few hundred years is pointless, because of the inequities of the radiocarbon calibration curve, but there are no alternative sources of dating until the twentieth century. It might therefore be assumed that Historical Archaeology has limited potential in a country such as Uganda. However, the burgeoning popular construction of history often has a questionable historical veracity and in a number of cases can be seen to actively ignore particular issues or places, creating 'silences' in their historical discourse. Historical Archaeology's great strength is that it can offer opportunities for delving into present day mindsets and psychoses through the exploration of the mundane and the subconscious. In particular, Historical Archaeology 
within Uganda offers the opportunity to challenge and critique the popular constructions of history that are being formed to help generate place and order in contemporary society. And in some respects it is the very recent archaeology that archaeologists have ignored around them, when undertaking their studies of long since passed time periods that are of greater historical relevance.

An excellent example lies in considering the excavations at Ntuusi between 1987 and 1991. The research provided a detailed understanding of the archaeology of one of the earliest political centres in the region dating between CE 1000 and $1600 .{ }^{32}$ Yet in many respects it was the world outside the excavation units and the things that were ignored that were of much greater significance. In the years in which the fieldwork took place the campsite used by the excavation team was in the open ground between the existing Gombolola (sub-county) headquarters and the local prison. It was obvious from the undulating ground that there were some archaeological features in the vicinity of the camp and in 1989 an excavation crew began work with the intention of broadening the examination of the ancient archaeological site. These excavations encountered the walls of a structure of some complexity and further excavation eventually revealed the outline of a multi-room, mud-walled building (Fig. 2). The material associated with this structure clearly indicated that it was twentieth century in date, featuring iron nails, blades and springs, glass, and crockery. An informant later identified the structure as being the original Ssaza/Gombolola headquarters built in the 1920s. As a former Muluka chief himself our informant could remember standing in a group in front of the building being berated by the Gombolola chief as the latter bestrode imperiously his veranda, looking down on the assembly below. This simple archaeology reveals the physical structuring of power in local administration within the colonial state. In this it

\footnotetext{
${ }^{32}$ See for example A. Reid, 'Ntusi and the development of social complexity in southern Uganda', in G. Pwiti and R. Soper (eds.), Aspects of African Archaeology: papers from the $10^{\text {th }}$ Congress of the Pan African Association for Prehistory and Related Studies (Harare, 1996), 621-7, and J.E.G. Sutton, 'The antecedents of the Interlacustrine kingdoms', Journal of African History, 34 (1993), 33-64.
} 
replicates the construction of Gombolola and Ssaza headquarters, built to a standard template, throughout Buganda and the affirmation of Buganda's authority in the new colonial world. These historical structures are now being lost as they are replaced by non-standardised buildings.

Clearly at Ntuusi confirming Buganda's power and authority was no simple process. Mawogola, within which Ntuusi lies, was a marginal location in the eighteenth and nineteenth centuries, caught between the different states. Buganda to the east expanded around the lake into Buddu, but Mawogola was too dry for banana cultivation and was not therefore a desirable place for settlement. Its grasslands were ideal for cattle herders from Nkore and Bunyoro, but the security of the herds could not be guaranteed at such great distance from the cores of these polities. The only herders who did frequent Mawogola would have been intentionally or otherwise declaring themselves independent from the politics of the western states, but as a consequence would have been susceptible to raiding and warfare by military parties, particularly from Buganda. In the nineteenth century, with almost no human inhabitants to exploit, Mawogola's principal value to Buganda was as a location for elephant hunters. ${ }^{33}$ The Buganda Agreement of 1900 , which saw the territory of Buganda significantly increase as part of the colonial settlement, included Mawogola within its territory. Thus, there was a necessary process by which marginal locations which were alien to the generally perceived nature of Buganda and its banana plantations were made part of the colonial state. Not only did the Gombolola headquarters, built to a standard design and sited on a hilltop that is visible from a distance of as much as fifteen kilometres in the surrounding landscape, physically confer this new identity and the presence of a new authority within the landscape, but the association was further strengthened by landscaping. One of the main features of this administrative hilltop in the present day is the tree lined avenue which runs from the main road up towards the current Gombolola headquarters. Yet the tree-lined portion of the avenue does not run directly to

\footnotetext{
${ }^{33}$ A. Reid, 'Archaeological ivory and the impact of the elephant in Mawogola', World Archaeology, 47 (2015), 467-85.
} 
this later building. Instead it is in direct alignment with the archaeological structure excavated in 1989. Most important of all, the avenue features trees known as kabaka njagala (the king loves me) and are the same species (Aleurites moluccanus) that line the avenue in Kampala running between the Lubiri (royal palace) and Bulange (Buganda parliament). This construction of landscape reveals the means by which Buganda's ideology and authority was extended to marginal areas in the early decades of the Uganda Protectorate.

Furthermore, the modern archaeology of this hilltop continues to play out broader political issues in Uganda. In the 1990s the site of the original Gombolola headquarters was built upon and thus the tree-lined avenue currently runs to the LC3 offices and the court room/meeting hall of the sub-county. The LC3 Chair is the effective and elected power within the sub-county, having been created by the NRM to control and even usurp the power of the appointed Gombolola and Ssaza chiefs. At Ntuusi therefore the LC3 administration have directly taken over the symbolic power of the Gombolola. This contestation of power and of physical space is by no means over. One of the main contentions within Uganda is the demands of Buganda for return of its property, including the structures associated with local administration, acquired by the state in the new constitution in 1967, after the abolition of the kingdoms. The extent of Buganda's claims and associated legal complications is further revealed by another issue relating to the archaeology of Ntuusi. In 2002, the President of Uganda himself recognised the need to protect the site at Ntuusi and under advice set in place the procedure for acquisition of several relatively small key locations within Ntuusi, giving the Minister for the Office of the President specific responsibility for over-seeing this procedure. It is a fair indication of the complexity of land ownership in Uganda that it took two years for this collective political weight to accomplish the task. ${ }^{34}$

\footnotetext{
${ }^{34}$ The matter was complicated by Ssembabule District having previously been part of Masaka and so land title archives had to be referred back to Masaka, but the greatest issue was that a number of the locations being acquired were situated on mailo land associated with the Gombolola and therefore owned by Buganda.
} 
This complexity in the siting and structuring of power in the twentieth and twenty-first centuries, and archaeology's unwitting place within it, is further highlighted by broader land issues within Mawogola. One of the major initiatives undertaken by the research programme between 1987 and 1991 was a systematic foot survey of the area surrounding Ntuusi to assess the nature of settlement. These walks to arbitrary points on the map revealed an amazing contemporary grassland environment inhabited by frequent homesteads of cattle keepers and very occasional fields of cultivators. My observations provided powerful interpretative insights on the past archaeological record, but there was a much more significant change taking place. Mawogola in the late 1980s was littered with the remains of the Ankole-Masaka ranching scheme of the 1960s and 1970s, whereby huge tracts of land were given over to wealthy interests encouraged to replace the inefficient rearing of the local longhorn Ankole cattle breed with the development of herds of imported animals that could be taken straight to market in Kampala. The turmoil of the 1970s and early 1980s not only impeded access to markets, but also discouraged the development of remote infrastructure within ranches. Most importantly, veterinary services and veterinary medicines became inaccessible and exotic animals died out. By 1987 the ranches were all but abandoned with their infrastructure left unmaintained and certainly no ranches sustained anything near the potential carrying capacity of the land. Instead the landscape was full of herder homesteads, both Hima and Tutsi, who were squatting on unused land in the hope that land reform promised by the NRM when it came to power would be acted upon. Eventually Banyarwanda in particular realised that, despite their active support for and participation in the NRA's insurgency, land ownership was essentially to remain tribally determined rather than citizen based. ${ }^{35}$ As early as 1987 I was made aware of fledgling Rwanda Patriotic Front activities in Mawogola and these were much more overt by 1990 resulting in conflict and unrest. Thus, the settlement distribution of herders, the overt material culture that they

\footnotetext{
${ }^{35}$ For a discussion of the link between the "Mawogola Uprising" and the invasion of Rwanda see M. Mamdani, When Victims Become Killers (Kampala, 2001), particularly 176-84.
} 
then surrounded themselves with, together with the ruined infrastructure of collapsed ranches all provided a material, and therefore archaeological, backdrop to the alienation of common land and subsequent social tension in Uganda, immediately prior to the invasion of Rwanda and the violence of the 1990s.

There are of course a whole range of issues that Historical Archaeology could successfully explore. Uganda has been characterised by major episodes of conflict and political intolerance. Into the early twenty-first century there were ready reminders of the defeat of Idi Amin's troops in the abandoned tanks and armoured cars left by the roadside in different parts of the south and west of the country in 1979, but these have now been removed and processed as scrap. In every gombolola headquarters in the 'Luwero Triangle' there are vaults in which have been placed the bones of victims of conflict in the early $1980 \mathrm{~s} .{ }^{36}$ After the resolution of the war in the north, communities have opted to try and preserve the displacement camps in which most people were forced to live. ${ }^{37}$

Equally there are a host of other potential historical contexts which could be explored and which would critique the 'obvious truisms' within Ugandan society. A possibility is a Historical Archaeology of iron production that takes into account historical attitudes towards iron smelting in colonial society and considers why Uganda's precolonial iron industries continue to be ignored in

\footnotetext{
${ }^{36}$ Amongst staff of other junior ministries, officers of the Department of Antiquities were ordered to participate in the collection process, noting, where evident, the cause of death, E.R. Kamuhangire, pers. comm. 1989. Not only did Peter Bisasso have to take part in the collection, but through family ties with the area, he was also aware of the main killing sites in the Nakaseke area, Peter Bisasso, pers. comm. 2000.

${ }^{37}$ J.D. Giblin, 'Post-conflict heritage: symbolic healing and cultural renewal', International Journal of Heritage Studies, 20 (2014), 500-18.
} 
popular consciousness. ${ }^{38}$ One influential history of Buganda, failed to mention iron working at all ${ }^{39}$ and reflects the absence of explicit association between iron working and power that contrasts so strongly with southern and western Uganda and neighbouring countries. ${ }^{40}$ Indeed, in relation to iron there is the potential to draw on toponymic evidence to trace past iron-working activity. The root ${ }^{*}$ tare, meaning iron ore, has a pronounced distribution across south western Uganda (Fig. 3$)^{41}$ and archaeological survey in such places tends to reveal numerous smelting locations. Most noteworthy is the cluster of locations in the far south western corner of the country which have received almost no attention to date.

Very little work has yet been done to explore the unique architecture that developed in relation to the Asian community. This combined elements of Asian architectural symmetry and symbolic designs, with art deco and other architectural techniques from the west and helped to construct Ugandan Asians place within the world and negotiated their relationships with other

\footnotetext{
${ }^{38}$ As one primary school teacher at Nabuganyi remarked during archaeological survey in 2000, "You Europeans brought science and technology to Africa", overlooking the abundant evidence for successful precolonial iron smelting that we were encountering.

${ }^{39}$ M.S.M. Kiwanuka, A History of Buganda: from the foundation of the kingdom to 1900 (London, 1971). R. Reid, Political Power in Pre-colonial Buganda (Kampala, 2002) provides a much fuller discussion and archaeological evidence is presented in A. Reid and R. Young, 'Iron smelting and bananas in Buganda', in P. Mitchell, A. Haour and J. Hobart (eds.), Researching Africa's Past (Oxford, 2003), 118-23, and J. Humphris, M. Martinón-Torres, T. Rehren and A. Reid, 'Variability in single smelting episodes - a pilot study using iron slag from Uganda', Journal of Archaeological Science, 36 (2009), 359-69.

${ }^{40}$ See Schmidt, Historical, P. de Maret, 'The Smith's myth and the origins of leadership in central Africa', in R. Haaland and P. Shinnie (eds.), African Iron Working: ancient and traditional (Oslo, 1985), 73-87, and H. Sassoon, 'Kings, cattle and blacksmiths: royal insignia and religious symbolism in the interlacustrine states', Azania, 18 (1983), 93-106.

${ }^{41}$ This data is sourced from the Uganda 1:50000 Map series.
} 
members of society. These structures, including houses, shops, and factories still exist as do the families that lived in them. It will also be essential to explore archaeology's historical attitude towards northern Uganda, as encapsulated in the tentative work at Agoro. In particular, it will be necessary to consider the means by which colonial academia helped to construct the idea of the historical and cultured south and the ethnographic and militaristic north and the ways in which Ugandans have played to these stereotypes.

These suggestions are simply drawn from personal experiences and encounters and are coloured by the particular places in which I have undertaken archaeological research but they reveal the huge potential for projects exploring the Historical Archaeology of Uganda. Notwithstanding limitations imposed by problems of preservation and the general mobility of populations and episodes of displacement that has taken place in recent times there are clearly opportunities for exploring questions of relevance both to the past and in the present day.

Historical Archaeology, therefore, has considerable potential for exploring issues of significance within Uganda, but its principle value should be for examination of more recent periods for which there are a better suite of historical sources. Rather than privileging written and predominantly European sources and perspectives, this focus on more recent historical episodes would enable the incorporation of multiple oral sources as well as the rash of historical writing undertaken by Ugandans in vernacular texts. It also must explore the complex and often contradictory generation of clan and sub-clan traditions, long recognised as a crucial alternative to homogenising court traditions. ${ }^{42}$ This will ensure the creation of a critically informed Historical Archaeology to challenge notions of history currently projected, rather than perpetuating colonial and neo-colonial paradigms. Historical Archaeology has the ability to explore the critical creation of history and encourage more effective national debate. Notwithstanding the problems associated

\footnotetext{
${ }^{42}$ See C. Buchanon, 'Courts, clans and chronology in the Kitara complex', in J. Webster (ed.), Chronology, Migration and Drought in Interlacustrine Africa (London, 1979), 87-124 and Kodesh, Beyond.
} 
with past attempts to explore the links between History and Archaeology from earlier times, the prospects for Historical Archaeology in Uganda would therefore appear to be considerable. 